\title{
Cytoplasmic Accumulation of Black Pigment
}

National Cancer Institute

\section{Source}

National Cancer Institute. Cytoplasmic Accumulation of Black Pigment. NCI Thesaurus.

Code C155960.

A morphologic finding indicating the presence of black pigment within the cytoplasm of cells in a tissue sample. 